\title{
Gender and the Pathogenesis of Gastrointestinal Diseases: The Role of Steroid Sex Hormones in the Development
}

\section{AM El-Tawil}

Department of Surgery, University Hospital Birmingham, United Kingdom

\begin{abstract}
The pathogeneses of gastrointestinal diseases are unclear. The strategy of any medical regimen for management of any disease is usually dependent on our understanding of the mechanism by which this disease has developed.

Different incidences of different gastrointestinal diseases in women from those in men suggest possible role of steroid sex hormones in the promotion or prevention of the development of these diseases. The present review is aimed at finding any clue that could help in improving our understanding and the outcome of management accordingly.
\end{abstract}

Conclusion: Steroid sex hormones play crucial role in the pathogenesis of several gastrointestinal diseases. Based on our findings in this survey, further studies are needed in order to determine how we could operate these findings in our clinical practice.

Keywords: Gastrointestinal diseases; Inflammatory bowel diseases; Functional bowel diseases; Fistula-in -ano; Idiopathic constipation; Peptic ulcer; Pathogenesis; Gender; Sex hormones; Epidemiology; Incidences

\section{Introduction}

Gastrointestinal diseases are recognized, as being dominant in women (Irritable bowel diseases, chronic constipation), but others, as being more common in men (Anal fistulae). These observations raise concerns about the involvement of sex steroid hormones in the pathogeneses of these diseases.

In order to examine this probability, we conducted a survey on a number of main common gastrointestinal diseases.

The outcome of this investigation was as followings:

\section{Peptic ulcers and sex hormones}

There is, sometimes, no clear evidence on potential role of sex hormones in inducing or modulating pathogenesis of gastrointestinal disorder. A hypothesis that they may act throughout potentiating the effect of other co-factors is possible. On the basis of experimental and clinical observations, it is known that ulcers of the gastroduodenal mucosa develop in a sexually dependent manner. For example, in the fertile age, peptic ulcer disease occurs more frequently among men than in women [1-3]. This sex- dependent differences may also be found in experimental models of mucosal damage, as oral administration of ethanol generated more severe gastric erosions in male rats than in females $[4,5]$. In this model of mucosal damage, gonadectomy protected the stomach against ethanol- induced injury only in male rats, but not in females [4].

Moreover, the administration of the testosterone receptor blockers, cyproterene acetate attenuated gastric haemorrhagic erosions in intact male rats following ethanol challenge.

In contrast, in a different model of gastroduodenal ulcers (as induced by restraint and forced exercise) the stomach of male rats was less sensitive to mucosal damage compared to that of females [6].

In conjunction to these findings, it can be suspected that sex hormones might possibly play a role in the development of gastroduodenal mucosal ulcer.
The actual sexual hormonal status of females may also be related to the generation of gastroduodenal ulcers. Pregnancy and lactation in rats markedly reduced steroid- and cysteamineinduced gastroduodenal lesions [7,8]. A lower incidence of peptic ulcers is also present in pregnant women [3] Moreover, during pregnancy, the frequency of haemorrhage and/ or perforation from gastroduodenal ulcers is lower compared to its high incidence in peurperium. Thus the elevation of endogenous progesterone plasma levels may be responsible for pregnancy -induced protection against mucosal ulcers, since early pregnant rats (with increased plasma oestrogen level) were less sensitive to gastroduodenal ulcers [8].

In addition, exogenous administration of $17 \mathrm{~B}$ estradiol into intact female rats increased mucosal damage induced by cysteamine [9].

\section{Bowel motility and sex steroid hormones}

The frequency of bowel movements in young women per week during the first half of the menstrual cycle where estrogen predominates was found almost half of those in males [10]. Yet, the colonic transit time was more prolonged during the second half where estrogen and progesterone predominate. Also, less often incidents of defecation per week in pre-menopausal than in post-menopausal women and in the last group than in men suggest some role of feminizing hormones in the pathogenesis of constipation.

Evidence exists from a few numbers of small studies that changes

*Corresponding author: AM El-Tawil, Department of Surgery, East Corridor Ground Floor, University Hospital Birmingham, Edgbaston, B15 2TH United Kingdom, Tel: 0044-121-6978231; Fax: 0044-1214466220; E-Mail: atawil20052003@yahoo.co.uk

Received February 10, 2011; Accepted February 12, 2011; Published February 13, 2011

Citation: El-Tawil AM (2011) Gender and the Pathogenesis of Gastrointestinal Diseases: The Role of Steroid Sex Hormones in the Development. J Steroids Hormon Sci 2:e101. doi:10.4172/2157-7536.1000e101

Copyright: (c) 2011 El-Tawil AM. This is an open-access article distributed under the terms of the Creative Commons Attribution License, which permits unrestricted use, distribution, and reproduction in any medium, provided the original author and source are credited. 
in gastrointestinal function occur in a cyclic pattern in menstruating women and may be related to cyclic variations in the ovarian hormones [11-15]. Even some constipated patients developed diarrhea just before menstruating. [12] Simmons et al reported prolonged gastrointestinal transit time during the luteal phase of the menstrual cycle where estrogen and progesterone predominate, when they compared their measurements with those recorded during the follicular phase where estrogen only predominates [16]. They also reported that the colonic transit time during the follicular phase was as twice as that in males [16]. The findings in this study were further supported by other publications $[17,18]$. In addition, when Ryan and colleagues [19] examined the colonic motility in five groups of rats they found higher duration of maximum electric activity in pregnant rats when compared with those in controls, ovariectomized, ovariectomized and treated with estrogen, and ovariectomized and treated with progesterone.

In another study, Wald and others [20] found that intestinal transit time as was measured by breath hydrogen level after lactulose ingestion, was longer on Days 18-20 (mid luteal) than on Days 8-10 (mid follicular). These findings were further confirmed by Heitkemper's report in 1992 [21]. It was a small study aimed at assessing the intestinal motility in 34 young females aged between 19-37 years, of who nine were on contraceptive pills, and they were followed for two successive menstrual cycles by Heitkemper's team. Heitkemper et al found differences in bowel patterns between midfollicular and luteal phases except in the subgroup that were on oral contraceptive pills. They also found an increase in stool consistency scores at menses when estrogen and progesterone levels were low or decreasing [21].

Stool pattern in women on contraceptive pills, whose ovarian hormones levels supposedly stable, remain relatively stable across the two phases of the menstrual cycle. They showed the greatest cyclerelated changes in stool consistency scores at menses. These findings suggest that important factor that influences stool pattern may be the amplitude of change (increase/decrease) in ovarian hormones levels, which occurs in normal menstrual cycle and in those on contraceptive pills.

A possible correlation between circulating levels of motilin and progesterone in normal pregnancy and early postpartum was investigated in a Chinese study [22]. Qiu XH reported that progesterone levels increased along with gestational age whereas motilin levels decreased. A significant negative correlation was found between the two hormones. He suggested that progesterone appeared to have a profound inhibitory effect on motilin. The decreased motilin level might partially be responsible for gastrointestinal hypomotility during pregnancy. These Chinese results were confirmed further by others' findings [23].

\section{Anal fistula development and gender}

The discrepancy in the incidence of non-specific fistula-in-ano between the adult males and females is well acknowledged. Sainio [24] in his population study over ten year period reported an incidence of 5.6:100 000 for females and 12.3:100 000 for males, with a male: female ratio of 1.8:1. Other quotes an even higher ratio, reaching 9:1 in some series [25]. This discrepancy suggests some protective role of female sex hormones against the development of idiopathic peri-anal fistula in women.

Acute infection of anal glands often results in the formation of a chronic intrasphincteric collection that may drain down to the perineum, up into the supralveolar compartment or across the sphincter into the ischiorectal fossa [26-28]. Abscess complicating an infection in an anal gland are caused by intestinal organisms and are variably associated with an internal opening at the outset. Drainage consequently often results in the creation of a track or fistula between the skin and anal mucosa at the dentate line. The conducted prospective study by Eykyn \& Grace in 1986 [29] evidently provides the most informative data on the causative agents in these cases. The participant patients had an initial examination under anaesthesia and a further examination, one week later, by an experienced surgeon to inspect the presence of a fistula. This clinical assessment was harmonized by an enormously inclusive microbiological survey. The significant microbiological findings are summarized in Table 1. This table provides an objective evidence to support the idea that gram negative bacteria are mainly responsible for the development of fistulae in those with anal abscess.

But whether sex hormonal receptors are exist on the surface of the anal tissue or not. This was answered by Oettling G and Franz HB [30]. In 1998, Oettling G and Franz HB [30] investigated the expression of androgen, oestrogen and progesterone receptors (ARs, ERs, PRs) in the tissues of the anal continence organ in 23 patients (seven men, seven premenopausal women and nine postmenopausal women) using immunohistochemical techniques. In their report, they concluded that specific immunostaining for ARs, ERs and PRs were found over cell nuclei. ARs were found in the smooth muscle cells of the internal anal sphincter in all but one of the females (10/11) and all males (7/7), ERs were found in 12/12 females and 4/7 males, and PRs were found in 4/10 females and 1/7 males. The squamous epithelium exhibited a similar pattern of immunostaining.

Two oestrogen receptor [ER] subtypes, named ER $\alpha$ and ER $\beta$ have been isolated and copied [31-33]. Vascularsmooth muscle and endothelial cells have been reported to express $E R \alpha$ and $\operatorname{Er} \beta$ protein \& mRNA [34-36]. Oestrogen has been proved to have anti-inflammatory effect by acting against inflammatory promoters, such as bacterial cell wall component, lipopolysaccharide (LPS) via activating ERa [37-42].

For investigating a probability that LPS (inflammatory promoter) could induce attenuation of ER expression by endothelial cells and this act could possibly be antagonized by oestrogen, a laboratory study was conducted by Holm and others [43]. They found that treatment with LPS $(10 \mathrm{ug} / \mathrm{ml})$ for 4 days attenuated iNOS protein expression by about $60 \%$, and reduced ER $\alpha$ mRNA expression by about $50 \%$ and $E R \beta$ mRNA expression by about $60 \%$. But stimulation with LPS (10ug/ml) for shorter time (16 hours) had no effect.

\begin{tabular}{|l|l|l|l|}
\hline Type of organism & fistula present $(\mathrm{n}=53)$ & No fistula $(\mathrm{n}=27)$ & \\
\hline $\begin{array}{l}\text { Number of abscesses } \\
\text { yielding anaerobes }\end{array}$ & $49(92.5 \%)$ & $8(29.6 \%)$ & $\mathrm{P}<0.0001$ \\
\hline Escherichia coli & $45(84.9 \%)$ & $5(18.5 \%)$ & $\mathrm{P}<0.0001$ \\
\hline $\begin{array}{l}\text { Staph. aureus } \\
\text { Anaerobes } \\
\text { 'Gut-specific } \\
\text { Bacteroids }\end{array}$ & $+1(1.9 \%)$ & $8(29.6 \%)$ & $\mathrm{P}=0.0012$ \\
\hline $\begin{array}{l}\text { Anaerobes not } \\
\text { 'gut-specific' (only) }\end{array}$ & $2(3.8 \%)$ & $5(18.5 \%)$ & $\mathrm{P}<0.000 \mathrm{I}$ \\
\hline $\begin{array}{l}\text { Gut aerobes+ } \\
\text { 'gut-specific } \\
\text { anaerobes' }\end{array}$ & $45(85 \%)$ & $17(63 \%)$ & $\mathrm{P}<0.0001$ \\
\hline
\end{tabular}

Includes E. coli, Klebsiella spp, Proteus spp, Citrobacter spp, Salmonella sp, Str faecalis

- + Only 2 colonies isolated.

This table is published with a permission from the Royal College of Surgeons of England

Table 1: Type of organisms isolated from anorectal abscesses with and without fistulae. 
Citation: El-Tawil AM (2011) Gender and the Pathogenesis of Gastrointestinal Diseases: The Role of Steroid Sex Hormones in the Development. J Steroids Hormon Sci 2:e101. doi:10.4172/2157-7536.1000e101

Holm and colleagues also found that dexamethasone (1uM) had no effect on the induced down regulation of ERa mRNA expression by LPS. This means that NF-B signalling pathway is not involved in LPS induced attenuation of ER gene expression (dexamethasone is known as an inflammatory inhibitor by acting against NF-B dependent transcription of pro-inflammatory genes) [44]. They, also, found that oestrogen increased mRNA expression in the presence of LPS. This may explain the lower incidences of anal fistulae in females than in males and raises a probability that oestrogen may be a promising effective therapy for these cases.

\section{Inflammatory bowel diseases \& gender}

In general there are no striking differences in the sex incidence of colitis or Crohn's disease. Variation of 1.5:1 [45-53] for excess of men or women, with either disease, with no general consistence from one country, or study group, to another. Given environmental association with smoking or probably with oral contraceptive use, it is difficult to believe that examination of the sex rates of the two diseases will yield significant clues to causes of disease frequency [54].

\section{Fissure in ano and gender}

There is often no apparent disorder which predisposes adult patients to anal fissure. Childbirth seems to be an associated factor in some women [55-57]. Martin in 1953 [57] reported that acute anal fissure occurred in association with recent childbirth in $11 \%$ of patients. Gough and Lewis [56] revealed that a previous history of parturition was more commonly associated with anterior fissures due to the pressure of the fetal head on the unsupported anterior anal mucosa. And this is likely the reason for the increasing number of diagnosed anterior fissures in women after vaginal delivery.

\section{Implications in research and clinical practice}

How to operate the findings in this survey in our current medical regimen necessitates further studies.

\section{References}

1. Cai S, García Rodríguez LA, Massó-González EL, Hernández-Díaz S (2009) Uncomplicated peptic ulcer in the UK: trends from 1997 to 2005. Aliment Pharmacol Ther 30: 1039-1048.

2. Aston NO, Kalaichandran S \& Carr JV (1991) Duodenal ulcer hemorrhage in the puerperium. Can J Surg 34: 482-483.

3. Michaletz-Onody PA (1992) Peptic ulcer disease in pregnancy. Gastroenterol Clin North Am 21: 817-826.

4. Laszlo F, Amani E, Varga C, Laszlo FA (1992) Influence of sex hormones on ethanol-induced gastric haemorrhagic erosions in rats. Acta Physiol Hung 80: 289-292.

5. Laszlo F, Amani E, Karacsony G, Szabo E, Rengei B, et al. (1993) The modulatory role of endogenous vasopressin in the phenomenon that orally administered ethanol generates more severe gastric erosions in male than in female rats. Ann NY Acad Sci 689: 623-626.

6. Robert A, Phillips JP, Nezamis JE (1966) Production, by restraint, of gastric ulcers and of hydrothorax in the rat. Gastroenterology 51: 75-81.

7. Kelly P \& Robert A (1969) Inhibition by pregnancy and lactation of steroidinduced ulcers in the rat. Gastroenterology 56: $24-29$

8. Montoneri C, Drago F (1997) Effects of pregnancy in rats on cysteamineinduced peptic ulcers: role of progesterone. Dig Dis Sci 42: 2572-2575.

9. Drago F, Montoneri C, Varga C, Laszlo F (1999) Dual effect of female sex steroids on druginduced gastroduodenal ulcers in the rat. Life Sci 64: 23412350.

10. Connell AM, Hilton C, Irvine G, Lennard-Jones JE, Misiewicz JJ (1965) Variation of bowel habit in two population samples. Br Med J 2: 1095-1099.
11. Jung HK, Kim DY, Moon IH (2003) Effects of gender and menstrual cycle on colonic transit time in healthy subjects. Korean J Intern Med 18: 181-186.

12. Heaton KW, Radvan J, Cripps H, Mountford RA, Braddon FE, et al. (1992) Defecation frequency and timing, and stool form in the general population: a prospective study. Gut 33: 818-824.

13. Rees WD, Rhodes J (1976) Altered bowel habit and menstruation. Lancet 1 475.

14. Wald A, Van Theil DH, Hoechstetter L Gavaler JS, Egler KM, et al. (1980) Gastrointestinal transit: The effect of the menstrual cycle. Gastroenteroly 80 : 1497-1500.

15. Lawson M, Everson GT, Klingesnsmith W, Kern F Jr (1983) Coordination of gastric and gallbladder emptying after ingestion of a regular meal. Gastroenterology 85: 866-870.

16. Simmons L, Heitkemper M, Shaver J (1988) Gastrointestinal function during the menstrual cycle. Health Care Women Int 9: 201-209.

17. Bruce LA, Beschudi FM (1981) Increased gastrointestinal motility in vitro following chronic oestrogen treatment in male rats. Proc Soc Exp Biol Med 166: 355-359.

18. Bruce LA, Beschudi FM (1980) Differential inhibition of regional gastrointestina tissue to progesterone in the rat. Life Sci 27: 427-434.

19. Ryan JP, Bhojwani A (1986) Colonic transit in rats: Effect of ovariectomy, sex steroid hormones, and pregnancy. Am J Physiol 251: G46-50.

20. Wald A, Van Theil DH, Hoechstetter L, Gavaler JS, Egler KM, et al. (1980) Gastrointestinal transit: the effect of the menstrual cycle. Gastroenterology 80 : 1497-1500.

21. Heitkemper MM, Jarrett M (1992) Pattern of gastrointestinal and somatic symptoms across the menstrual cycle. Gastroenterology 102: 505-513.

22. Qiu XH (1993) Relation between motilin concentration and progesterone leve in normal pregnancy and early postpartum. Zhonghna Fu Chan Ke Za Zhi 28 524-6, 568.

23. Cheng L, Pricolo V, Biancani P, Behar J (2008) Overexpression of progesterone receptor $B$ increases sensitivity of human colon muscle cells to progesterone. Am J Physiol Gastrointest Liver Physiol 295: G493-502.

24. Sainio $P$ (1984) Fistula-in-ano in a defined population. Incidence and epidemiological aspects. Ann Chir Gynaecol 73: 219-224

25. Eisenhammer S (1985) Emergency fistulectomy of the acute primary anorecta cryptoglandular intermuscular abscess-fistula in ano. S Afr J Surg 23: 1-7.

26. PARKS AG (1961) Pathogenesis and treatment of fistuila-in-ano. Br Med J 1 463-469.

27. EISENHAMMER S (1956) The internal anal sphincter and the anorectal abscess. Surg Gynecol Obstet 103: 501-506.

28. EISENHAMMER S (1961) The anorectal and anovulval fistulous abscess. Surg Gynecol Obstet 113: 519-520.

29. Eykyn SJ, Grace RH (1986) The relevance of microbiology in the management of anorectal sepsis. Ann R Coll Surg Engl 68: 237-239.

30. Oettling G, Franz HB (1998) Mapping of androgen, estrogen and progesterone receptors in the anal continence organ. Eur J Obstet Gynecol Reprod Biol 77 211-216.

31. Green S, Walter P, Kumar V, Krust A, Bornert JM, et al. (1986) Human oestrogen receptor cDNA: sequence, expression and homology to v-erb-A. Nature 320 134-139.

32. Greene GL, Gilna P, Waterfield M, Baker A, Hort Y, et al. (1986) Sequence and expression of human estrogen receptor complementary DNA. Science 231 $1150-1154$.

33. Kuiper GG, Enmark E, Pelto-Huikko M, Nilsson S, Gustafsson JA (1996) Cloning of a novel estrogen receptor expressed in rat prostate and ovary. Proc Natl Acad Sci U S A 93: 5925-5930.

34. Mendelsohn ME (2002) Protective effects of estrogen on the cardiovascular system. Am J Cardiol 89: 12E-17E; discussion 17E-18E.

35. Hodges YK, Tung L, Yan XD, Graham JD, Horwitz KB, et al. (2000) Estrogen receptors alpha and beta: prevalence of estrogen receptor beta mRNA in human vascular smooth muscle and transcriptional effects. Circulation 101:1792-1798. 
Citation: El-Tawil AM (2011) Gender and the Pathogenesis of Gastrointestinal Diseases: The Role of Steroid Sex Hormones in the Development. J Steroids Hormon Sci 2:e101. doi:10.4172/2157-7536.1000e101

Page 4 of 4

36. Andersson C, Lydrup ML, Fernö M, Idvall I, Gustafsson J, et al. (2001) Immunocytochemical demonstration of oestrogen receptor beta in blood vessels of the female rat. J Endocrinol 169: 241-247.

37. Liang M, Nilsson BO (2004) Proteasome-dependent degradation of ERalpha but not ERbeta in cultured mouse aorta smooth muscle cells. Mol Cell Endocrinol 224: 65-71.

38. Vegeto E, Belcredito S, Etteri S, Ghisletti S, Brusadelli A, et al. (2003) Estrogen receptor-alpha mediates the brain antiinflammatory activity of estradiol. Proc Natl Acad Sci USA 100: 9614-9619.

39. Liu CJ, Lo JF, Kuo CH, Chu CH, Chen LM, et al. (2009) Akt mediates 17betaestradiol and/or estrogen receptor-alpha inhibition of LPS-induced tumor necresis factor-alpha expression and myocardial cell inhibition of LPS-induced tumor necresis factor-alpha expression and myocardial cell apoptosis by suppressing the JNK1/2-NFkappaB pathway. J Cell Mol Med 13: 3655-3667.

40. Cerciat M, Unkila M, Garcia-Segura LM, Arevalo MA (2010) Selective estrogen receptor modulators decrease the production of interleukin- 6 and interferongamma-inducible protein-10 by astrocytes exposed to inflammatory challenge in vitro. Glia 58: 93-102.

41. Lewis DK, Johnson AB, Stohlgren S, Harms A, Sohrabji F (2008) Effects of estrogen receptor agonists on regulation of the inflammatory response in astrocytes from young adult and middle-aged female rats. J Neuroimmunol 195: 47-59.

42. Pozzi S, Benedusi V, Maggi A, Vegeto E (2006) Estrogen action in neuroprotection and brain inflammation. Ann N Y Acad Sci 1089: 302-323.

43. Corbacho AM, Eiserich JP, Zuniga LA, Valacchi G, Villablanca AC (2007) Compromised aortic vasoreactivity in male estrogen receptor-alpha-deficient mice during acute lipopolysaccharide-induced inflammation. Endocrinology 148:1403-1411.

44. Holm A, Andersson KE, Nordström I, Hellstrand P, Nilsson BO (2010) Downregulation of endothelial cell estrogen receptor expression by the inflammation promoter LPS. Mol Cell Endocrinol 319: 8-13.

45. Fenta YA, Tello N, Jung JA, Urm SH, Loftus EV Jr, et al. (2010) Inflammatory bowel disease and asthma: a population-based, case-control study. Inflamm Bowel Dis 16: 1957-1962.

46. Veluswamy H, Suryawala K, Sheth A, Wells S, Salvatierra E, et al. (2010) African-American inflammatory bowel disease in a Southern U.S. health center BMC Gastroenterol 10: 104.

47. Blumenstein I, Bock H, Zosel C, Dignass AU, Hartmann F, et al. (2009) Are there gender-related differences in the therapeutic management of patients suffering from inflammatory bowel disease? Subgroup analysis of a prospective multicentre online-based trial. Z Gastroenterol 47:1045-1051.

48. Russel MG, Dorant E, Volovics A, Brummer RJ, Pop P, et al. (1998) High incidence of inflammatory bowel disease in The Netherlands: results of a prospective study. The South Limburg IBD Study Group. Dis Colon Rectum 41: $33-40$.

49. Miller DS, Keighley AC, Langman MJ (1974) Changing patterns in epidemiology of Crohn's disease. Lancet 2: 691-693.

50. Evans JG, Acheson ED (1965) An epidemiological study of ulcerative colitis and regional enteritis in the Oxford area. Gut 6: 311-324.

51. Kyle J (1971) An epidemiological study of Crohn's disease in Northeast Scotland. Gastroenterology 61: 826-833.

52. Fahrländer H, Baerlocher C (1971) Clinical features and epidemiological data on Crohn's disease in the Basle area. Scand J Gastroenterol 6: 657-662.

53. Calkins BM, Lilienfeld AM, Garland CF, Mendeloff AI (1984) Trends in incidence rates of ulcerative colitis and Crohn's disease. Dig Dis Sci 29: 913-920.

54. Langman MJS (1993) Inflammatory Bowel Diseases In: Gastroenterology: Clinical Science and Practice; $2^{\text {nd }}$ edition. W.B.Saunders Pages: 1067-1075.

55. Abramowitz L, Sobhani I, Benifla JL, Vuagnat A, Daraï E, et al. (2002) Ana fissure and thrombosed external hemorrhoids before and after delivery. Dis Colon Rectum 45: 650-655.

56. Gough MJ, Lewis A (1983) The conservative treatment of fissure-in-ano. Br J Surg 70: 175-176.

57. MARTIN JD (1953) Postpartum anal fissure. Lancet 1: 271-273. 